\title{
Immobilization of Hansenula polymorpha Alcohol Oxidase for Alcohol Biosensor Applications
}

\author{
Hyun-Jung Chung, Hyun-Young Cho, and Kwang-Hoon Kong* \\ Department of Chemstry, College of Natural Sciences, Chung-Ang Lniversity, Seoul 156-756, Korea \\ E-mail: khkongácau ackr \\ Recerved Atrgust 30, 2008, Accepted October 22, 2008
}

\begin{abstract}
Alcohol oxidase catalyzes the oxidation of short lines alcohol to aldehyde. In this study, alcohol oxidase from Hansenula polymorpha (HpAOD) was induced by addition of $0.5 \%$ methanol as the carbon source and purified to electrophoretic homogeneity by column chromatographies. 'The purified $H p A O D$ was immobilized with DEAE-cellulose particles and its biochemical properties were compared with those of free enzyme. The substrate specificity and the optimum $\mathrm{pH}$ of innobilized enzyme were sinilar to those of free enzy me On the other hand, the $K_{\mathrm{m}}$ values of free and inmobilized enzymes for ethanol were 6.66 and $14.65 \mathrm{mM}$, respectively. The optimum temperature for free enzyme was $50^{\circ} \mathrm{C}$, whereas that for inmobilized enzy'me was $65^{\circ} \mathrm{C}$. Immobilized enzy me showed high stability against long storage. Innobilized enzy me was also tested for the enzymatic detemination of ethanol by the colorimetric method. We detected $1 \mathrm{mg} / 1$ iter ethanol $\left(1 \times 10^{-1} \%\right.$ ethanol) by 2,6 -dichloroindophenol sy stem. Therefore, the present study demonstrated that immobilized $H p A O D$ has high substrate specificity toward ethanol and storage stability; which may be of considerable interest for alcohol biosensor and industrial application.
\end{abstract}

Key Wonds: Hansenula polymorpha. Alcohol oxidase. Biochemical properties. Immobilization. Stabiliț

\section{Intoduction}

Alcohol oxidase (alcohol: oxygen oxidoreductase, EC 1.1.3.13. AOD) is an oligomeric enzyme with eight identical subunits. each containing a non-cov alently bound flavine adenine dinucleotide molecule (FAD) as a cofactor. ${ }^{1,2}$ AOD catalyzes the oxidation of primary low molecular weight alcohols into the corresponding aldelydes. During this reaction. cofactor (FAD) in AOD is first reduced to its hydrogenated form $\left(\mathrm{FADH}_{2}\right)$ and then re-oxidized to its native form by molecular oxygen $\left(\mathrm{O}_{2}\right)$. with the concomitant formation of hydrogen peroxide $\left(\mathrm{H}_{2} \mathrm{O}_{2}\right)$.

One of the most relevant applications of AOD has been the monitoring of ethanol in the beverages and fermentation industries. clinical chemistry and forensic analysis. ${ }^{3}$ The accurate quantification of ethanol with high sensitivity and selectivity in biological fluids such as plasma and urine and in human breath is required for clinical and forensic laboratories. The industries such as production of alcoholic beverages. food-stuffs. cosmetic and phammaceuticals are very interested in fast analytical methods to control fenmentation process and product quality. A variety of methods and strategies for the analysis of ethanol in complex samples have been reported including liquid and gas chromatography, refractometry and spectrophotometry. , $^{4,5}$ On contrary to conventional methods. the application of enzy mes allows to considerable enhancement of specificity and thus decreases the expenditure for sample pretreatment."

AOD has also attracted major scientific interest for use in the bioconversion of ethanol to acetaldehyde. Acetaldehyde is an important bulk chemical and is mostly used for purposes of acetic acid synthesis. "Moreover. acetaldehyde is used as a fragrance and flavor additive by the food indistry. ${ }^{8}$ Some bioconversion processes have been described utilizing alcohol dehydrogenases. either purified or in tact cells. for the convert- sion. ${ }^{9}$ However, alcohol dehydrogenase requires a cofactor, $\mathrm{NADH}$. which needs continuous regeneration. As an alternative. AOD does not require cofactor regeneration. "Bioconversion of ethanol to acetaldehy de has been reported using either purified AOD or intact AOD-containing cells from methylotrophic yeasts. . $^{\varepsilon, 9,11,12}$

In these respect, immobilized AOD is advantageous over the native enzy me because of its thernal resistance and tolerance towards the common denaturing reagents. and it is preferred over the native ones owing to their multiple and repetitive use. Furthermore. immobilized enzyme has a longer life time and predictable decay rate. . $^{\text {s-1 }}$ ?

In this study. alcohol oxidase from Hansenula polvmorpha was induced purified and immobilized with DEAE-cellulose particles. The biochemical properties of inmobilized enzy me were compared with those of free enz'me. We also described the colorimetric method for ethanol determination by inumobilized enzyme.

\section{Materials and Methods}

Materials. Hansenula polvmorpha (A.T.C.C. 26012) was obtained from Korean Culture Center of Microorganisms in freeze-dried form. Yeast nitrogen base without amino acid. yeast extract and bactopeptone were obtained from Difco Laboratories (Detroit. USA). 2.6-Dichloroindophenol (DCIP). $2.2^{\prime}$-azino-bis(3-ethylbenzthiazoline-6-sulfonic acid (ABTS), leticene (zymolyase) and peroxidase were purchased from Sigma (St Louis. MO. USA). DEAE-Sephacel and Mono Q HR 5/5 were obtained from Phanmacia Biotech (Uppsala, Sweden). Protein-assay reagent and SDS-PAGE molecular mass markers were purchased from Bio-Rad (Hercules, CA. USA). All reagents used were of the highest grade available commercially.

Expression and puification of alcohol oxidase from 
Hansenula polymorpha. Cells of the methylotrophic yeast Hansentla polmmorpha were grown with shaking in YNB medium $(0.7 \%$ yeast nitrogen base without amino acid. $0.1 \%$ yeast extract and $0.05 \%$ bacto peptone) at $37^{\circ} \mathrm{C}$ for $16-24$ hours. Alcohol oxidase was strongly induced by addition of $0.5 \%$ methanol as the carbon source. The cells were harvested by centrifugation at $10.000 \mathrm{~g}$ for $10 \mathrm{~min}$ and then were suspended in $50 \mathrm{mM}$ tris- $\mathrm{HCl}$ buffer contained $10 \mathrm{mM} \mathrm{MgCl}$. 1 $\mathrm{M}$ sorbitol and $30 \mathrm{mM}$ dithiothreitol. $\mathrm{pH} 7.5$. The cells were subjected to the addition of zymolyase ( $200 \mathrm{U}$ ) for 40 minutes and to sonication using an ultrasonic processor (Sonics and Materials. Danbury. CT. USA) until lýsed. The disrupted cell suspension was centrifuged at $40.000 \mathrm{~g}$ for $60 \mathrm{~min}$. y ielding the crude extracts. The supernatant was dialyzed against 50 mM potassium phosphate buffer, $\mathrm{pH} 7.5$ (buffer $\mathrm{A}$ ) and loaded on to a DEAE-Sephacel column $(1.6 \times 40 \mathrm{~cm})$ previously equilibrated in buffer A. After washing the column with buffer $A$, bound proteins were eluted with a linear gradient of 0 $1 \mathrm{M} \mathrm{NaCl}$ in buffer $\mathrm{A}$ at a flow rate of $0.25 \mathrm{ml} / \mathrm{min}$. Fractions containing enzyme activity were pooled, dialyzed against buffer A. and loaded on to a Mono Q HR 5/5 column equilibrated in buffer $A$. The column was washed with buffer $A$ and bound proteins were eluted with a linear gradient of 0.500 $\mathrm{mM} \mathrm{NaCl}$ in buffer $\mathrm{A}$ at a flow rate of $0.5 \mathrm{~mL} / \mathrm{min}$. Active fractions were pooled and were dialy zed against buffer $\mathrm{A}$. The purified enzyme was essentially homogeneous as judged by SDS-PAGE (data not shown) and the specific activity of the enzyme toward ethanol was approximately $10 \mathrm{Unit} / \mathrm{mg}$. This purified enzyme was used for an immobilization experiment. Unless otherwise indicated, all purification procedures were performed either at $4^{\circ} \mathrm{C}$ or on ice. The enzy'mes were stored at $-70^{\circ} \mathrm{C}$ until use.

Activation of DEAE-cellulose with cyanuric chloride. The DEAE-cellulose was activated by slightly modified method proposed by Tiller et al. ${ }^{18}$ The pre-swollen DEAE-cellulose was washed and suspended with distilled. The suspended solution was saturated by sodium hydroxide. The remaining sodium hydroxide in the solution was removed by filtration. The DEAE-cellulose was added to a solution of $100 \mathrm{mg}$ of cyanuric chloride dissolved in $10 \mathrm{ml}$ of $1: 1(\mathrm{w} / \mathrm{w})$ dioxane-xylene solution and incubated at room temperature for $30 \mathrm{~min}$. The activated surface was then thoroughly rinsed with ethanol until it became clear. washed with $50 \mathrm{mM}$ potassium phosphate buffer containing $1 \mathrm{mM}$ EDTA. $\mathrm{pH} 7.5$. and immediately placed into an enzyme solution in the same buffer. which had previously been cooled to $4^{\circ} \mathrm{C}$

Enzyme immobilization. The purified enzyme (300 Units) was mixed with the activated cellulose support ( $1 \mathrm{~g}$ ). After incubation at $4^{\circ} \mathrm{C}$ for 24 hour, the nonattached enzyme was removed by rinsing with $1 \mathrm{M} \mathrm{NaCl}$. The supernatant was taken to determine the concentration of free enzymes. and the enzyme immobilized-cellulose was used for the assay after washing several times with buffer. For each experiment. three replicates were studied and an average of the three was taken as the result.

Enzyme assay and linetic studies. Alcohol oxidase-catalysed reactions were routinely perfonned spectrophotometrically at $405 \mathrm{~nm}$ in coupled assays with $2.2^{\prime}$-azino-bis-(3-ethỵl- benzthiazoline-6-sulphonic acid) (ABTS) and peroxidase as described by Tani et al. (1985). ${ }^{19}$ Molar absorbance coefficient of ABTS was $36.800 \mathrm{M}^{-1} \cdot \mathrm{cm}^{-1}$ and one unit of enzy me activity was defined as the amount of enzyme that catalyzed the generation of $1 \mu$ mole of $\mathrm{H}_{2} \mathrm{O}_{2}$ per min under the above experimental conditions. Specific activity was expressed as units per milligram of protein. Kinetic parameters were deternined by Lineweaver-Burk plot method ${ }^{210}$ The enzyme concentration used for initial-rate studies was $1 \sim 50$ $\mu \mathrm{g} / \mathrm{ml}$ and the concentration of ethanol was varied over the range $0.1 \sim 100 \mathrm{mM}^{2]}$ The protein concentration of the enzyme was detennined by the method of Bradford using '-globulin as standard. ${ }^{22}$

Enzyme stability. The stabilities of the enzy mes were determined by using native and immobilized enzymes with a protein concentration of $0.1 \mathrm{mg} / \mathrm{ml}$. The enzymes were incubated in buffer A at $4^{\circ} \mathrm{C}$ or $25^{\circ} \mathrm{C}$ over 7 weeks. At the end of the storage period. the remaining activity was determined.

Colonimetic method of the enzymatic analysis for detemination of ethanol. For the direct deternination of ethanol using the enzy me. $1.5 \mathrm{ml}$ of $10 \mathrm{mM}$ potassium phosphate buffer (pH 7.5) containing specific amounts of imnobilized AOD. peroxidase of 4 units/ml and $100 \mathrm{mM} 2.6$-dichloroindophenol (DCIP) was mixed with $0.5 \mathrm{ml}$ of an ethanol solution (in the same buffer) of known concentration and incubated at $25^{\circ} \mathrm{C}$. DCIP was well soluble in water and hence could be unifornly dispersed during the preparation of the preparation of the enzyme-support power. The absorbance spectnum in the visible range for an aqueous solution of this conpound in its oxidized form had a maximum at $610 \mathrm{~nm}$. Consequently. the reaction was monitored by measuring changes in absorbance at this wavelength using a spectrophotometer.

\section{Results and Discussion}

Catalytic properties and stahilities of fiee and immobilized enzymes. The inmobilization of $H p A O D$ was performed with the activated cellulose support as mentioned in the Materials and Methods. The substrate specificity of inumobilized enzyme towards several compounds was shown in Table 1. A number of primary. secondary and tertiary alcohols were used to determine the substrate specificity of immobilized enzyme. A gradual decrease in rate was observed by branching of the carbon chain of the alcohol. Immobilized enzyme oxidized mainly primary aliphatic alcohols and exhibited high substrate specificity towards ethanol and methanol. On the other hand immobilized enzy me didn't show activity towards long chain primary alcohols. short chain secondary alcohols and tertiary alcohols. This substrate specificity of inmobilized enzyme was similar to free enzyme. although immobilized enzyme showed approximately $20-30 \%$ lower activities than those of free enzyme.

The kinetic parameters of free and inmobilized enzymes were shown in Table 2 . The maxinum reaction rate ( $F$ ' max) describes the rate of reaction between enzyme and its substrate. ethanol and Michaelis-Menten constant $\left(K_{\mathrm{m}}^{*}\right)$ defines the affinity of enzyme toward ethanol. The $r$ max value of immobilized enzyme for ethanol was $15.38 \mathrm{U} / \mathrm{mg}$. This value is similar to 
Table 1. Substrate specificity of tree $H p A O D$ and immobilized $H p A O D$

\begin{tabular}{|c|c|c|c|c|}
\hline \multirow{2}{*}{ Substrates } & \multicolumn{2}{|c|}{ Free $H p A O D$} & \multicolumn{2}{|c|}{ Immobilized $H p A O D$} \\
\hline & Specitic Activity (U/mg) & Relative Activity (\%) & Specific Activity (U/mg) & Relative Activity (\%) \\
\hline 1-butanol & $0.04 \pm 0.002$ & 04 & $\mathrm{ND}^{a}$ & - \\
\hline 2-butanol & $N D^{4}$ & - & $\mathrm{ND}^{\prime \prime}$ & - \\
\hline 3-butanol & $\mathrm{ND}^{a}$ & - & $\mathrm{ND}^{a}$ & - \\
\hline crotyl alcohol & $0.68 \pm 0.03$ & 6.6 & $0.48 \pm 0.01$ & 5.9 \\
\hline ethanol & $10.23 \pm 0.51$ & 100 & $8.18 \pm 0.43$ & 100 \\
\hline isoamyl alcohol & $0.02 \pm 0.001$ & 0.2 & $\mathrm{ND}^{a}$ & - \\
\hline methanol & $948 \pm 0.32$ & 92.7 & $6.68 \pm 0.62$ & 81.7 \\
\hline 1-propanol & $0.21 \pm 0.02$ & 2.1 & $0.33 \pm 0.004$ & 40 \\
\hline 2-propanol & $0.01 \pm 0.001$ & 0.1 & $\mathrm{ND}^{a}$ & - \\
\hline 2,2,2-trichloroethanol & $0.02 \pm 0.002$ & 0.2 & $\mathrm{ND}^{a}$ & - \\
\hline
\end{tabular}

"ND, Not detected. The values showed are Means \pm S.D., generally based of $n \geq 5$.

Table 2. Kinetic parameters tor tree $H p A O D$ and immobilized $\mathrm{HPAOD}$

\begin{tabular}{lcc}
\hline & Vree $H p \mathrm{AOD}$ & Immobilized HpAOD \\
\hline$K_{\mathrm{m}}$ (112M) & 6.66 & 14.65 \\
$I_{\text {max }}(\mathrm{U} / 111 \mathrm{~g})$ & 17.24 & 15.38 \\
\hline
\end{tabular}

The values showed are means. generally based of $n \geq 3$.

that of free enzyme (17.24 U/mg). The $K_{\mathrm{m}}$ values of free and immobilized enzymes for ethanol were determined as 6.66 $\mathrm{mM}$ and $14.65 \mathrm{mM}$. respectively. Higher the $K_{\mathrm{m}}$ value means lower its affinity against its substrate. Thus, immobilized enzyme has a weaker affinity toward ethanol than free enzyme. From these results on the substrate specificity and the kinetic parameters. we suggest that immobilization of HpAOD did not largely affect the correct orientation between the active site of enzyme and substrate, although it may more or less affect substrate binding in enzyme-substrate complex.

The biochemical properties of immobilized enzyme were investigated with ethanol oxidation reaction. The effects of $\mathrm{pH}$ on ethanol oxidation by free and immobilized enzymes were shown in Figure 2. The optimum activity of immobilized enzyme on ethanol was observed in $\mathrm{pH} 8.5$. Immobilized enzyme showed less than $45 \%$ of its maximum activity below $\mathrm{pH}+.0$ and appeared approximately $85 \%$ of its maximum activity even at $\mathrm{pH} 10.0$. Similar result was also found in free enzyme.

Immobilized enzy me was shown to be active over a wide range of temperatures (from 30 to $80^{\circ} \mathrm{C}$ ). The optimum temperature of immobilized enzyme was $65^{\circ} \mathrm{C}$ and up to $25 \%$ of activity was observed even at $80^{\circ} \mathrm{C}$. On the other hand, the optimum temperature of free enzyme was $50^{\circ} \mathrm{C}$. The thermostability of immobilized enzyme was investigated by in-

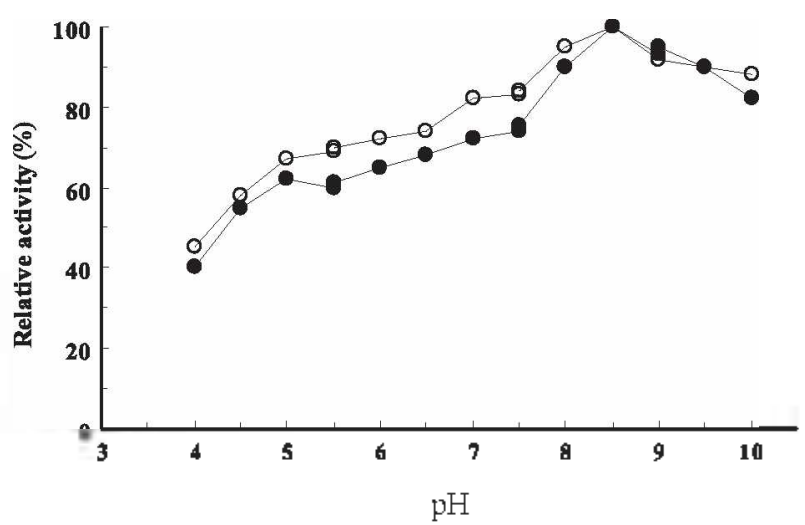

Figure 2. Effect of $\mathrm{pH}$ on tree $H p \mathrm{AOD}$ and immobilized $H p \mathrm{AOD}$. The buffer conditions as follow: $\mathrm{pH} 3.5-5.5,100 \mathrm{mM}$ sodium acetate buffer: $\mathrm{pH} 5.5-7.5,100 \mathrm{mM}$ potassium phosphate butfer. $\mathrm{pH} 7.5-9.0$, $100 \mathrm{mM}$ Tris-HCl buffer, $\mathrm{pH} 90-100.100 \mathrm{mM}$ sodium carbonate-bicarbonate buffer. The maximum activity was expressed 100\%. Indicate that tree $H p A O D(--)$ and immobilized $H p A O D(--)$.

cubation of the enzyme at various temperatures for $10 \mathrm{~min}$. The nidpoints of the temperature-stability curve for free and immobilized enzymes were approximately $54^{\circ} \mathrm{C}$ and $63^{\circ} \mathrm{C}$. respectively. Immobilized enzyme was fairly stable at temperature up to $60^{\circ} \mathrm{C}$. Above $70^{\circ} \mathrm{C}$. its activities declined rapidly as the temperature increased but immobilized enzyme was not completely inactivated even at $80^{\circ} \mathrm{C}$. Therefore. immobilization of $H p$ AOD with the activated cellulose support supplies a higher stability.

Enzymes can lose their catalytic activity and be denaturated easily. Hence, storage stability is a very important factor for the practical use of enzyme in biosensors or as biocatalysts. Immobilized enzyme showed a high storage stability and retained approximately $90 \%$ of its original activity even after

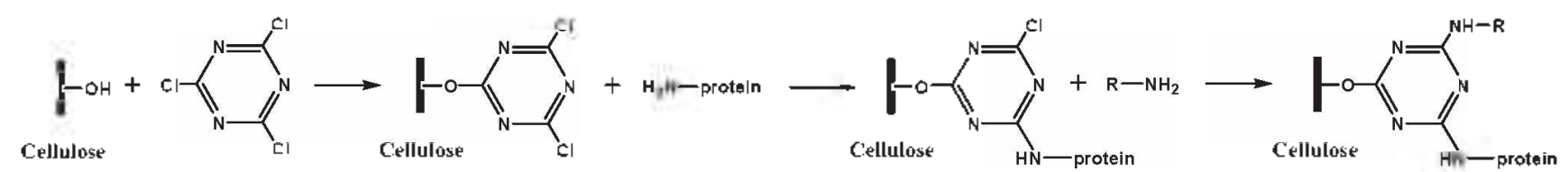

Figure 1. Schematic diagram for the activation of cellulose by cyanuric chloride and immobilization of $H p A O D$ by covalent linkage. 


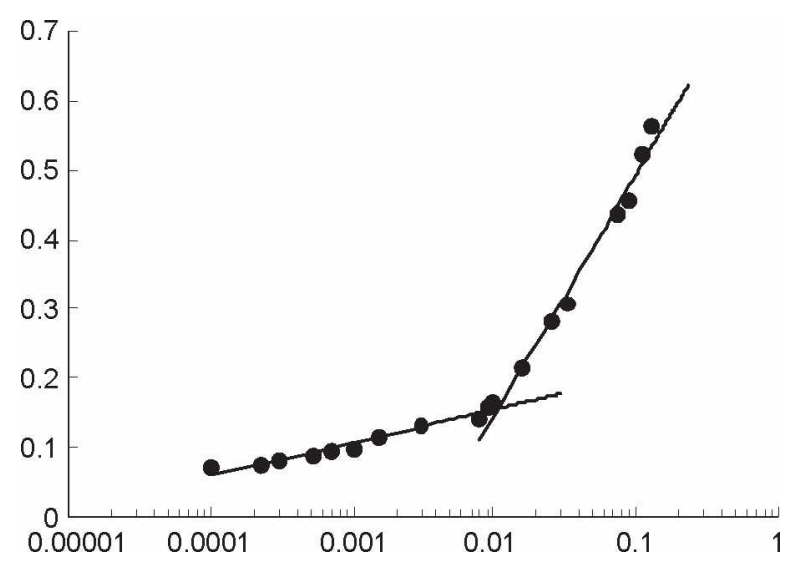

Figure 3. Detemmination of ethanol concentration using inmobilized HpAOD with DCIP system. The concentration of DCIP is proportional to the original ethanol concentration and can be deter- mined by its absorbance at $610 \mathrm{~nm}$.

10 weeks at $4^{\circ} \mathrm{C}$. On the other hand free enzyme retained $70 \%$ of its original. At $25^{\circ} \mathrm{C}$. immobilized enzyme retained approximately $60 \%$ of its original activity after 10 weeks. On the other hand, free enzyme retained only $20 \%$ of its original activity. These results indicate that immobilized enzyme has very good stability at 4 "C and can be safely used in 10 weeks. This stable immobilized $H p A O D$ may be useful for the enzymatic determination of alcohol and for the industrial production of alcohols and aldehydes.

The detemination of ethanol concentration using immobilized enzyme. Alcohol oxidase catalyzes the oxidation of alcohols to aldehydes and has been used extensively for the determination of ethanol in body fluids. ${ }^{23.44}$ We performed by evaluating a chromogenic agent, 2.6-dichloroindophenol (DCIP) for its ability to develop a stable and distinct change in color when subjected to peroxidase-catalyzed oxidations. The reaction scheme is as follows:

$$
\begin{gathered}
\mathrm{CH}_{3} \mathrm{CH}_{2} \mathrm{OH}+\mathrm{O}_{2} \rightarrow \mathrm{CH}_{3} \mathrm{CHO}+\mathrm{H}_{2} \mathrm{O}_{2} \\
\mathrm{DCIP}_{\text {oxidzej }}+\mathrm{H}_{2} \mathrm{O}_{2} \rightarrow \mathrm{DCIP}_{\text {decornposed }}+\mathrm{H}_{2} \mathrm{O}
\end{gathered}
$$

The enzymatic system composed of immobilized $H p A O D /$ peroxidase/DCIP oudized $_{\text {was }}$ characterized in aqueous solution, and the results obtained were shown in Figure 3. As the response to ethanol in the range $1-1.500 \mathrm{mg} /$ liter ethanol $\left(1 \times 10^{-4}-1.5 \times 10^{-1} \%\right)$ was not linear. the calibration curves were transformed the values of ethanol concentration by $\log$ to obtain the linear dependencies. Similar behavior of ethanol biosensors has been described. ${ }^{24}$ Under the experimental conditions the lowest detectable ethanol concentration was 1 $\mathrm{mg} /$ liter ethanol $\left(\mathrm{I} \times 10^{-4} \%\right)$ and the calibration curve was linear up to concentrations of $100 \mathrm{mg} /$ liter ethanol $\left(1 \times 10^{-3} \%\right)$. Moreover. the procedure was very rapid showing the detection time of $1 \mathrm{~min}$. The calibration curve was also linear in the range $100-1.500 \mathrm{mg} /$ liter ethanol $\left(1 \times 10^{-\hat{-}}-1.5 \times 10^{-1} \%\right)$. The detection limit of this colorimetric method was significantly lower than those of other methods for alcohol determination. 5 and it was sufficient to monitor ethanol in clinical applications with reference to urine or blood.
In conclusion. we purified an AOD from $H$. polvmorpha and immobilized the punfied enzyme with the activated cellulose support. The substrate specificity, the kinetic parameters and the optinum $\mathrm{pH}$ of inmobilized enzyme were similar to those of free enzyme although distinct features can be pointed out. as mentioned above. Particularly. inmobilized enzyme has a higher stability and it was useful for the enzymatic determination of alcohol with DCIP system.

Acknowledgments. This research was supported by the Chung-Ang University Research Grants in 2008.

\section{References}

1. Vonck, L.; van Bruggen, E. F. T. Biochim. Biophys. Acta 1990, 1038, 74 .

2. de Hoop, M.: Asgeirsdottir, S.; Blaauw; M.: Veenhuis, M.: Cregg, I.: Gleeson, M: Ab, G. Protein Eng. 1991, f, 821

3. Azevedo, A. M.; Cabral, T. M. S.; Gibson, T. D.; Fonseca, L. P. J. Hol Catal B: Enzmm. 2004, $28,45$.

4. Liden, H.: Vijayakumar, A. R.; Gorton, L.; Marko-Varga, G. J. Pham. Biomed. 1998, 17, 1111 .

5. Yarita, T.; Nakajima, R.; Otsuka, S.; Ihara, T.; Takatsu, A.; Shibukawa, M. J. Chromatogr. 4 2002, 976, 387.

6. Patel, N. G.: Meier, S.: Camman, K.; Chemnitils, G. C. Sens. Actuators B: Chem 2001, 75, 101

7. Hagemeyer, H. J.Acetaldehty in Kirk-Other Encyclopedia of Chemical Techrolog, $4^{\text {th }}$ ed.; Kroschwitz. I. I.; Howe-Grant, M., Eds.: John Wiley \& Sons: New York, 1991: Vol. 1, p 94.

8. Welsh, F. W. Murray, W. D.; Williams, R. E. Crit. Rev. Biotechmol $1989,9,105$

9. Murray, W. D.; Duff, S. J. B.; Lantier, P. H.; Armstrong, D. W Welsh, F. W.; Williams, R. E. Dev. Food Sci. 1988, 17, I.

10. Woodward, J. R. In Autonophic Aficrobiology and One-cabon Metabolism: Codd, G. A.: Dịkhuizen, L, Tabita, F. R., Eds; Dordrecht: Kluwer, 1990; p 193.

11. Sakai, Y: Tani, Y. Agric. Biol Chent 1987, 51, 2617.

12. Tani, Y. In Biolog' of Hethylotrophs; Goldberg. I., Rokem, J. S., Eds.: Boston: Butterworth-Heinemann, 1991: p 253.

13. Isik, S.; Alkan, S.; Toppare, L.; Cianga, I.; Yagci, Y. Eum Potm. J. $2003,39,2375$.

14. Przy byt, M:- Bialkowska, B. Haster: Sci. 2002, 20,63

15. Guzman-Vazquez de Prada, A.; Pena, N.; Partado, C.; Reviejo, A. J.: Pingarton, J. M. Talanta 2004, 62,896.

16. Patel, N. G.; Meier, S.; Cammant, K.; Chemnitius, G. C. Sens. Actuators $B$ : Chent 2001, 75, 101

17. Rezaei-Zarchi, S.: Saboury, A. A.: Hong, I.: Norouzi, P.; Moghaddam, A. B.: Ghourchian, H.: Ganjal, M. R.; MoosaviMovahedi, A. A.; Javed, A.; Mohammadian, A. Bull. Konecn Chem. Soc: $2007,28,2266$.

18. Tiller, I. C.: Rieseler, R: Berlin P.; Klemm, D. Biomacromolecules 2002, 3, 1021

19. Tani, Y.; Sakai, Y; Yamada, H. Agric. Biol. Chent 1985, $19,2699$.

20. Lineweaver, H, Burk, D. J. Ant. Chem. Soc. 1934, 56,658 .

21. Koh, T. U.; Cho, H. Y.; Kong, K. H. Bull. Konean Chem. Soce. 2007, 28, 772 .

22. Bradford, M. M. Anal. Biochem. 1976, 72, 248.

23. Hopkins, T. R.; Muller, F. In Microbial Growth on Cl Compounds; Van Verseveld, H. W; Duine. T. A., Eds.; 1987; p 150 .

24. Barzana, E.: Klibanov, A. M.; Karel, M. Anal Biochem. 1989. 182,109

25. Mohr, G. J.; Citterio, D.; Spichiger-Keller, U. E. Sens. Actuators $B 1998,+9,226$

26. Matsumoto, K:; Matsubara, H.: Hamada, M.; Ukeda, H:; Osaijima, Y.J. Biotech 1990, 14, 115. 